\title{
EFL PRE-SERVICE TEACHERS' IDENTITY CONSTRUCTION DURING TEACHING PRACTICE PROGRAM
}

\author{
Indra Yoga Prawiro ${ }^{1}$; Ghina Amaliah ${ }^{2}$ \\ ${ }^{1}$ indrayoga@unwir.ac.id; ${ }^{2}$ Ghina1598@gmail.com \\ ${ }^{12}$ English Education Department, Wiralodra University - Indramayu
}

\begin{abstract}
Professional teachers are an essential element in realizing the quality of education (Boyle, 2013). The teaching practice program is conducted as one of the training programs to become professional teachers for the pre-service teachers. During this program, EFL pre-service teachers begin to construct their teacher identity with various images of teachers. This case study explored the process of the pre-service teachers' identity construction from the perspective of sociocultural theory and the factors that contribute to the process. By distributing interviews and personal narratives to three EFL pre-service teachers in Wiralodra University, findings demonstrated that the process of pre-service teachers' identity construction is complex and personal. The teachers' identity construction involves both personal and social perspectives. From a personal perspective, it involves emotions and the self (self-image and self-esteem), and social perspective involves experiences and social interaction. This study also found that the preparation of materials and the choice of suitable methods and media for learning became challenges for the pre-service teachers. In addition, the pre-service teachers' identity construction is influenced by some factors. For example, they were mentoring and supervising, tensions, identity recognition, previous teaching experiences, pedagogy, content-area knowledge, relationship with students. That led to the development of pre-service teachers' identities.
\end{abstract}

\section{Keywords: identity construction, pre-service teacher, teaching practice program}

\section{INTRODUCTION}

Teaching practices are believed to help the pre-service teachers to construct their identity through interactions during the activity. Beauchamp and Thomas (2019) supported that teachers' identity is shaped and reshaped in interaction with others in a professional context. As the first step of pre-service teachers' career, the educational process starts assuming more responsibilities and positions as actual teachers in their study program and practicums, Salinas \& Ayala (2018) along with their studying period in university. Furthermore, while becoming a teacher, the preservice teacher may construct a new identity, transform an identity, adapt their understandings and ideals to institutional realities, and decide how to express themselves in classroom activity (Rodgers \& Scott, 2008).

Some studies have reported that the teaching practice can affect the construction of teachers' identity. For example, a study done by Harun (2019) implicates the need for a teaching practice program that would assist the student teachers' construction of professional identity as prospective teachers. In comparison, a study by Zacharias (2010) indicates that the teachers' identity can change mediated explicitly by the critical pedagogy in the teaching practice program. The third study done by Cattley (2007) concluded that student teachers' experiences in teaching practice programs help to construct teachers' identity. Unlike those studies, this study explores the undergraduate English as a foreign language (EFL) pre-service teachers' identity construction process at Wiralodra university, adopting sociocultural perspective from Vygotsky 
theory and the factors that contribute to pre-service teachers' professional identity construction. Therefore, this study focuses on how EFL pre-service teachers construct their professional identity throughout the teaching practice program and the factors that contribute to their identity construction.

\section{LITERATURE REVIEW}

\section{The Concept of Teacher Identity}

TI is fundamentally linked to the concept of 'who am I?' and 'who are you?' which comprise internal (personal) and external (social) realities. The former entails cognition, while the latter denotes roles. The internal images constructed by teachers, which are considered vital in developing teacher identity, come from a lengthy process that starts in their experiences as learners (Borg, 2004; Malderez et al., 2007).

For example, during this time, professional expectations, motivations, emotions, and core beliefs about teaching and learning emerge. The experiences gained in classrooms, the notion of what education is about, and the capacity to judge models of good and bad teachers enable prospective teachers to construct a predefined idea of what makes a teacher. This source of experiential knowledge is strengthened with professional or theoretical knowledge as they enroll in a teacher education program (Johnson, 2009). Community and practice are vital constructs in understanding the meaning of being a teacher and, consequently, professional identity. In other words, classroom practice helps teachers to get a real sense of the role of the teacher. These general domains evolve as a dynamic process resulting from the experience of becoming a teacher: learning to teach trajectory where all of the constructs described here come together to frame the meaning and identity of teachers.

In summary, the teachers' identity is seen as relational, negotiated, constructed, enacted, changed, and transitioned (Miller, 2008). It is not a permanent property of a teacher. Still, rather a process that evolves, changes, or refuses as the teacher gets to experience, consolidating professional knowledge, and adopting personal plans and professional development (Tsui, 2003). This process is greatly influenced by the cultural and socio-political context where the teacher lives and works.

\section{Sociocultural Perspective of Learning on Identity Construction}

Vygotsky describes learning as a social process and the origination of human intelligence in society or culture. The sociocultural perspective considers that self-consciousness arises not from the individual, but social relations with others, and the individual dimension of consciousness is derivative and secondary (Vygotsky, 1979). Thus, the perspective emphasizes social participation, the relationship and interaction with others, activity settings, and historical change (Scribner, 1997).

The term identity was not directly discussed in Vygotsky's sociocultural theory. However, he was concerned with individuals' developmental processes of what today we refer to as the study of identity. The concepts of sociocultural theory Practice: (classroom roles) Teacher Identity: personal and social images Knowledge \& beliefs: (the self) Experience: (classroom practice) A teacher Community (participation, interaction) such as high-level mental functions, mediation, internalization, and symbols are often discussed concerning identity (Vygotsky, 1979).

The basic concept of this perspective is to include the external conditions of life in which human beings live to explain the highly complex forms of human consciousness. Thus, identity is constructed through the meaning the person gives to symbols in society when interacting with the cultural and social contexts; the individual internalizes these meanings by means of the mental functioning process (Penuel \& Wertsch, 1995). Thus, personal and contextual factors are involved in teacher identity construction.

\section{Teacher Identity Construction}


Within the sociocultural process, the identities of teachers are constructed from a social and personal perspective (Beauchamp \& Thomas, 2009; Johnston, 2012). From a personal perspective, teacher identity (TI) construction involves 15 agencies, emotions, meaning systems, and the 'self'. It refers to the meaning of self toward teacher identity and includes the quality of becoming a teacher (Beauchamp \& Thomas, 2009). And from a social perspective, this involves the influence of context, traditions, experiences, social interactions, and positions (Beauchamp $\&$ Thomas, 2009). Teacher identities are primarily shaped by daily interactions and interactions practices that characterize school life (Yon, 2000).

According to Sleegers and Kelchtermans (1999), teacher identity is influenced by technical and emotional dimensions of the teaching profession, such as subject knowledge and classroom management issues, but it is also constructed as the result of an interaction between the personal experiences of teachers and the social, cultural, and institutional environment in which they function on a daily basis. All these personal and social factors are intertwined and result in a process where teachers can constantly negotiate and reshape their identities in communities through social interactions and experiences.

\section{Factors of Identity Construction}

Identity is an ongoing process that leads the pre-service teachers to adapt their understanding and transform their identity to develop their professional identity. Beijaard, Verloop, \& Vermunt (2000) argue that the pre-service teachers deal with some factors that contribute to their identity construction during this ongoing process. One of the factors might be external, which refers to the people in contact with the pre-service teachers. Lerseth (2013) argues that mentoring and supervising teachers become the factors that influence their identity especially during their teaching practice in the natural school setting. Besides, Gee (2000) also argues that identity recognition and tensions become the factors that contribute to their identity construction. Specifically, these factors influence what pre-service teachers believe about who a teacher is.

In addition, Gee (2000) also states that pre-service teachers' beliefs about who a teacher is are connected with the teachers' action. Following this, Beijaard et al. (2000) mention that past experience, content area knowledge, pedadagogy, and relationship with students influence preservice teachers' belief in what a teacher should do, which become the other factors that contribute to the transformation. Thus, this study will use factors of identity transformation proposed by Lerseth (2013), Gee (2000), and Beijaard, Verloop, \& Vermunt (2000). Those factors are: mentoring and supervising teachers, tensions, identity recognition, previous teaching experience, pedagogy, content area knowledge, relationship with students.

\section{METHOD}

This study aimed to explore how the EFL pre-service teachers construct their professional identity and the factors that contributed to the processes throughout their teaching practice program. In order to achieve this aim, the writer needed to gather in-depth data of the English pre-service teachers' experiences during their teaching practice. In this study, three EFL preservice teachers, one male and two females are purposively taken as participants. All of them were enrolled in the final year of a four-year Sarjana Pendidikan Degree program, majoring in English education department faculty of teachers training and education science, at the Wiralodra University in Indramayu. Thus, referring to the aim, the study belonged to a case study, and it framed in a qualitative paradigm since it explores a complex, dynamic, and immeasurable process such as the construction of identity (Norton \& McKinney, 2010). The interview and personal narratives in this study were used to get the data. According to Ary (2010) an interview is an instrument to gather data from people about their opinion, belief, and feeling about the situation in their own words. An interview was conducted to gain an in-depth understanding of the pre-service teacher's teaching practice experiences. Besides, the writer used personal narratives as the supporting data. Taylor and Littleton (2006) remark that teachers' personal narratives can be seen as a version of their identity work. To organize and analyze the data, the writer employed Creswell's (2012) qualitative data analysis. 


\section{FINDING AND DISCUSSION}

This study aimed to answer the research questions; the process of EFL pre-service teachers' identity construction and the factors that contributed to the processes throughout their teaching practice program. The interview was the first instrumentation in this study. It contained twenty one questions that was categorized into two categories. The first is the pre-service teachers' identity construction which is described at questions number 1 to 6 and 17 to 21 . The second is the factors that contribute to the pre-service teacher's identity construction, which are described in questions 7 to 16. Three pre-service teachers from Wiralodra University filled it. Then the second instrument is the personal narratives. Pre-service teachers wrote a narrative about their experiences in the teaching practice program. Here are the finding as well as the discussion of the research.

\section{The way of EFL pre-service teachers constructs their professional identity throughout teaching practice program.}

This case study examined teacher identity construction among three pre-service teachers during their teaching practice experience. Guided by three competing yet complementary theoretical frameworks for investigating teachers' professional identities (e.g., Gee, 2000-2001; Bijaard, Meijer, \& Verloop; Moje \& Luke, 2009). The first research question focused on how the preservice teachers construct their professional identity construction. Each participant has the same placement with the same mentors and supervisors. In this study, the pre-service teachers' identities develop as revealed through their teaching experiences, each participant constructing their professional identity uniquely and interestingly. For each participant, the construction of their identity is personal and different. Although some aspects may be similar, these data reveal that identity development is very complex and personal.

\section{a. Emotions}

$\mathrm{P} 1$ in her teaching practice program placement provided an excellent look into her thoughts and emotions during her teaching practice program placement. At one point, she stated that she had mixed feelings about the teaching practice program. P1 stated "I felt challenged and shocked at the first time. It was because the atmosphere was so different from when I tech in microteaching. I had to adapt to the new situation that I faced, in which all of the students had the different characteristics". This is in line with Nutriansi (2015), who states that the students, setting, and many other factors can be manipulated in micro-teaching. Meanwhile, the environment and condition during the teaching practices at a real school setting have less or even do not have possibility of being manipulated. Specifically, it is because it takes place at a real school where the pre-service teachers taught real students they had not met.

Similarly, P2 shared his emotions at the beginning of his teaching practice program placement he stated "I was very nervous because I taught at one of the schools that can be said to be elite in this city. So, it stressed me out. I am afraid that it will not turn out as I expected". This is line with Suwannaset \& Rimkeeratikul (2014) who stated that pre-service teachers often felt anxiety in teaching practice programs. In addition, P3 shared her emotions during the teaching practice program she stated "I felt so amazed, I mean amazing in this case is, I have so many unpredictable situations. Sometimes what I learned in university just say in micro-teaching class is totally different with what I got in the real school". Therefore, she also found some differences such as students' characteristics. It follows that emotions are central to the construction of teacher identity. They contribute to shaping teachers' state of mind and attitudes in the classroom, thereby influencing teaching. This is supported by the research findings by Sutton \& Wheatley (2003) who found that emotions play a key role in understanding commitment to change, the quality of teaching, and as well as identity. That emotions can affect teacher cognition and teacher motivation.

\section{b. Self-Image}


In the context of self-image, in this study all the participants have different image of the role of the teacher, P1 stated in her interview "I think the role of a teacher depends on the situation, there is one side of us act as their friend, one side as parents and one side as a complete teacher, as a mentor who nurtures and provides knowledge to the students". She emphasized that it was essential in order to make the students were close and open to them. It is supported by Iswandari (2016) who stated that a teacher is not only a teacher but also a parent which could create safe and comfortable classroom atmosphere. Furthermore, P2 stated "In my opinion, a teacher has to act as a teacher should do. Even though we are still a pre-service teacher, we must act like a real teacher. For me, teacher was someone who facilitated the students during the teaching and learning activities". Generally, he tended to put himself as a students' friend rather than as a teacher. Furthermore, he emphasized that during his teaching practice, he focused more on assisting and guiding the students in the teaching-learning process. Besides, he also managed himself to have good relationship and be friendly with the students. Finally, as a learning facilitator, he also often made the best use of learning media, which promoted students' understanding. This is line with $\mathrm{Xu}$ (2013) who states that the teacher is someone who focuses on the students' learning process and becomes a facilitator in the teaching-learning process.

Moreover, P3 mentioned in the interview "I believed that teachers should be a guide for the students. In this case when we become the guider for the students, you know the gap is not too far. So, we can build the close relation with the students, when we have the close relation with the students, it will be easier for us to make students involve in the learning activity. I underlined that the teachers' role is belong to the guider and the controller". More specifically, she mentioned that as a teacher she should give affection and care to the students. In this particular context, she also emphasized that as a teacher she often dealt with students' personal emotion and characteristics during the teaching practice program. In the interview, she stressed that she also focused on giving the learning needs include the students' needs, the material needs, and the school needs. This is in line with Harden (2000) who argues that a teacher facilitates the learning process rather than to act simply as an information provider.

\section{c. Self-esteem}

In the context of teachers' changing before and after teaching practice or self-esteem P1 and P3 believed that being a teacher was not only about teaching but it has a lot of preparation and responsibility. As P1 stated, "In my opinion, the teachers' changing before teaching practice is at first, I thought that a teacher was just someone who had to manage the class well, someone who only teaches the students but, actually being a teacher is a complicated job, because I have to prepare a lot of things." P1 emphasized that being a teacher is indeed not easy because teachers should prepare a lot of things in case of preparation of the material before teachinglearning process. This is line with Michelli and Earley (2011) who stated that a teacher needs to do a lot of things such as preparation, implementation, and evaluation before conducting teaching-learning activity. Further, P2 and P3 also considered that as teachers they had to be able to become good role models who led the students become a good human being. They stated that teachers are responsible for the social behavior in their classroom. This is line with Bashir, Bajwa, and Rana (2014) who said that teachers play an essential role in the school. Students often mimic a teacher's actions. Teachers are responsible for the social behavior in their classrooms. This behavior is primarily a reflection of the teacher's actions and the environment she sets. Teachers have a long-term impact on the lives of their students, and that the most outstanding teachers inspire their students to glory. Furthermore, P2 also stated in his interview after teaching practice she realized that a teacher should dress well, because it influences how the students saw him as a teacher inside and outside the school.

In this connection, identity involves a continuous process of entering oneself into a profession. While this is true, each pre-service teacher also notes how stressful and tiring student teaching can become. Making connections between coursework and practical applications can be a difficult transition for many people. The data revealed that challenge was present in each of the participants' pre-service teachers' teaching experiences in the teaching practice program. 
Most of the challenge was caused by the preparation of materials and the choice of methods and media for learning. They found difficulty to choose suitable media and method to teach the students. Furthermore, P2 also stated that the other challenge she faced during teaching practice is sometimes she felt confused in order how to engage students' attention to focus on learning activity. Moreover, P3 also noted that most of the students in the school got a course outside the school, so it made a challenge for the pre-service teacher to prepare the material as best as possible.

\section{The factors that contribute to the pre-service teacher's identity construction}

However, the data attempts to answer questions about how these particular pre-service teachers report their identity construction during their teaching practice program and certain factors that contribute to the construction of pre-service teacher professional identification. However, some core factors affect identity development during their teaching practice program. There are no new factors contributed, the factors found in this study just confirm from the factors stated by Gee (2000), Beijaard et al. (2000), and Lerseth (2013) they are state that there are seven factors that contribute to the pre-service teachers' identity construction. After the data analysis process was complete, a total of seven themes emerged. For each of the seven themes a claim was made, data was provided to support the claim and finally connections to current research and/or practical educational benefits were presented. However, they considered that there were three factors namely identity recognition, relationship with the students, and relationship with mentoring and supervisor as the major factors. On the other hand, the research participants considered the other four factors as minor factors which contributed to their identity construction. These four factors were pedagogy, tensions, previous teaching experience, and content-area knowledge.

\section{A. Major Factors of Pre-service Teachers' Identity Construction}

In this section, the writer would like to discuss the major factors that contributed to pre-service teachers' identity transformation. There were three major factors, namely relationship with the students, identity recognition, and relationship with mentor and supervising teacher.

\section{1) Relationship with Students}

The first theme identified is the relationship with students. Each of the participants stated that they have a good relationship with the students. Like P2 stated in the interview, "Actually, I got along with them well. Some of them were very close to me and felt comfortable. By getting along with them, I had many opportunities to help them learn the materials and therefore they could improve their performance". This is in line with Beijaard, Verloop, and Vermunt (2000) who state that when the pre-service teachers develop productive relationship with their students, they get to know them and take particular interest in their overall development and progress. As a result, these supportive relationships helped all the pre-service teachers understand their students more, which affected their teaching practice and contributed to their identity construction.

\section{2) Identity Recognition}

The second factor that affects a pre-service teacher's identity development is identity recognition. One of the crucial things in teacher preparation is pre-service teachers' understanding of themselves. Moreover, it is also critical to take prior identity development and see how it merges with new development through experiences which are happening now. In relation to this, Gee (2000) argues that identity related to what kind of person. Specifically, identity recognition, in this case, refers to how pre-service teachers and other people acknowledge them as teachers during the teaching practice. Each of the participants experienced identity development throughout their teaching practice program. As stated by P1 in the interview "I always want to be a teacher who is close to the students, I put myself as my students' friend and also their teacher a someone who they trust, to make them feel comfortable 
with the teaching-learning activities. So automatically when teaching I apply it as much as possible, I don't want students to feel tense in my class so as much as possible I tried to run a fun class". In this case, the recognition of his identity influenced the way he put himself in the classroom practice. He devotes himself regularly to personal communication with students fostering positive relationships between teacher and students. This is line with Hamre \& Pianta (2006) who stated that it has a positive effect that maintains student interest in the academic and social fields. Gee (2000) supported that who says that it is essential to understand how a person identifies himself or herself because who a person is related to how he or she acts. In other words, it was clear that all the participants knew how to act and put themselves as teachers during the teaching practice. As mentioned previously, this is in line with Gee (2000) who argues that identity recognition helps someone to recognize himself or herself and affects how he or she acts.

\section{3) Mentoring and Supervising Teacher}

The third factor which affects a pre-service teacher's identity development is the mentor/supervisor experience and connections. During the teaching practice program, preservice teachers dealt with people around them who influenced their teaching practice and became one of the factors of pre-service teachers' identity transformation. Specifically, these people were supervising and mentoring teachers. Supervising teacher, in this case, was provided by the college and observed the pre-service teachers weekly or depending on the pre-service teachers' need. Besides, a mentoring teacher is the teacher who constantly contacts the preservice teachers and observes them. In accordance to this, Lerseth (2013) states that mentoring teacher and supervisor are people who are consistently in contact with them and attend during the teaching practice program. In accordance with this, P1, P2, and P3, who tended to construct their identity, considered their mentoring still influenced them enough during the teaching practice program as mentioned in the interview "I have learned a lot of things from my mentoring teacher. She was a kind and disciplined teacher. She helped me design my lesson plans, gave me constructive feedback, and trusted me to handle some classes when she could not attend the meeting. She taught me some tricks to handle "naughty" students as well." During his teaching practice, $\mathrm{P} 2$ also mentioned that his mentoring teacher suggested that he improve his time management as constructive feedback. This idea is in the same line as Lerseth (2013), who states that mentoring teachers' suggestion and feedback are needed to influence pre-service teachers' teaching practice. It shows that P2 with her mentor teacher builds a good relationship. That statement is in line with Saphier, Haley-Speca \& Gower (2008), who stated that to function as a team, communication and positive interaction are necessary ingredients needed for clarity of purpose and for collaboratively guiding, mentoring, and supporting pre-service teachers.

Furthermore, P1 believed that her supervisor influenced her teaching during the teaching practice. P1 stated, "My supervisor was very caring. She always gives some advice for my teaching practice activity in the classroom. Therefore, it boosted my spirit to teach the way I wanted to teach". P2 considered his supervisor influenced him by showing her kindness and some advice towards the pre-service teacher. So that it boosted the P2's spirit to teach during teaching practice. That statement is in line with Zepeda (2012), who believed providing preservice teachers feedback and advice about levels of student engagement in their classrooms was the most important behavior. Since pre-service teachers are still learners, in which they need knowledgeable people around them to help on their journey (Lerseth, 2013). The preservice teachers need feedback and suggestion from others especially their mentoring or supervising teacher. In other words, supervising and mentoring teachers need to work with the pre-service teachers to improve their teaching (Hoben, 2006).

\section{B. Minor Factors of Pre-service Teachers Identity Construction}

In this section, the researcher would like to discuss the minor factors contributing to pre-service teachers' identity transformation. 


\section{1) Pedagogy}

The next theme presented in this chapter indicates that a teacher's pedagogy or teaching philosophy impacts their identity development. This factor was common among all participants; however, one of the pre-service teachers focused more on their teaching through reflection and questioning the impact they made on their students. While, the other pre-service teachers focused more on their mentor's pedagogical decisions and the differences they would have done if they were the lead teacher.

\section{2) Tensions}

The next factor is tension, which can impact positively or negatively, depending on the situation. The pre-service teachers must experience heightened tension to help shape teacher identity. These assumptions align with Phelan (2005) indications that heightened anxiety and strong emotional experience can help share an identity. Tension was apparent through three modes of themes: (a) institutional pressure, (b) change in philosophy, and (c) turning-points. Changes in philosophy and turning-points were very individual tensions experiences and are discussed in more length under the second research questions. However, institutional pressure was present for each of the three participants. The data revealed a disconnect between what preservice teachers expect a classroom to look and feel like and how it operates.

\section{3) Previous Teaching Experience}

The next factor that affected their identity construction during the teaching practice program is previous teaching experiences. In this particular context, pre-service teachers' prior teaching experience gave them teaching experience. It is because identity is a continuum, where what they know about themselves now and what they have learned help them to construct or shape themselves in future activities. The P1 found that her previous teaching experiences helped her how to manage a classroom well. In comparison, P2 and P3 found that their experiences in last teaching helped them in designing an appropriate lesson plans.

\section{4) Content Area Knowledge}

The next factor that affects a pre-service teacher candidate's identity development is that a teacher's content area knowledge determines how they teach. In this study, all the pre-service teachers agreed that their content area knowledge led them in creating the teaching and learning process. P1 found that her public speaking courses helped her a lot in speaking English fluently in front of the students. While P2 and P3 found that their content area knowledge helped them master the material. Significantly, the course that related to the teaching is beneficial.

The data presented above indicate that each of the pre-service teachers did construct identity during their student teaching placement. The differences in how that identity is formed are an intriguing phenomena. Results demonstrate that each pre-service teachers' path to identity construction is individual and personal. This can make the task seem daunting to aid in a preservice teacher candidates' development; however, by understanding that the continuum of identity is individual, colleges and universities can help by providing the space, time, and experiences to allow pre-service teacher candidates to examine their identity and the growth that they need to make individually.

\section{CONCLUSION}

This case study examined teacher identity construction among three pre-service teachers during their teaching practice program experience one of Senior High School in Indramayu. In the data presented, generally, the pre-service teachers in this study mentioned that they involve emotions, the self, experiences, and social interactions during the teaching practice program. As teachers, they tended to become teachers who could guide students' minds, spirits, and pursuits. It is indicated that each pre-service teacher did indeed establish an identity during their student teaching practice program. However, for each participant, the construction of their identity is personal and different. Although some aspects may be similar, these data reveal that identity 
development is very complex and personal. Besides that, the data analysis showed that the participants considered some factors that contributed to their teachers' identity construction. These factors influenced the pre-service teachers in doing their job as teachers, and they believed to be good teachers. There were seven factors that affected their identity during the teaching practice program. However, they considered that there were three factors: identity recognition, relationship with the students, and relationship with mentoring and supervisor. On the other hand, the research participants considered the other four factors as minor factors that contributed to their identity construction. These four factors were pedagogy, tensions, previous teaching experience, and content-area knowledge.

\section{REFERENCES}

Ary, D., Jacobs, L. C., Sorensen, C., \& Razavieh, A. (2010). Introduction research in education. Belmont, CA: Wadsworth.

Bashir, S., Bajwa, M., \& Rana, S. (2014). Teacher As A Role Model And Its Impact On The Life Of Female Students. International Journal of Research - Granthaalayah Vol.1. No. 1 , 9-20.Beauchamp, C., \& Thomas, L. (2009). Understanding teacher identity: An overview of issues in the literature and implications for teacher education. Cambridge Journal of Education, 39(2), 175-189.

Beijaard, D., Verloop, N., \& Vermunt, J. D. (2000). Teachers' perceptions of professional identity: An exploratory study from a personal knowledge perspective. Teaching and Teacher Education, 16, 749-764.

Beauchamp, C., \& Thomas, L. (2009). Understanding teacher identity: An overview of issues in the literature and implications for teacher education. Cambridge Journal of Education, 39(2), 175-189

Borg, M. (2004). The apprenticeship of observation". ELT Journal 58 (3): 274276.

Boyle, C. (2013). Pre-service Secondary Teachers' Attitudes Towards Inclusive Education. Australian Journal of Teacher Education, 38(4).

Cattley, G. (2007). Emergence of Professional Identity for the Pre-Service Teacher. International Education Journal, 8(2), 337-347.

Creswell, J, W. (2012). Educational Research: Planning, Conducting and Evaluating Quantitative and Qualitative Research (Fourth Edition). Boston: Pearson Education.

Gee, J. P. (2000). Identity as an analytic lens for research in education. Review of Research in Education, 25, 99-125.

Hamre, B. K., \& Pianta, R. C. (2006). Student-Teacher Relationships. In G. G. Bear \& K. M. Minke (Eds.), Children's needs III: Development, prevention, and intervention (pp. 5971). National Association of School Psychologists.

Harden, R. M. (2000). The integration ladder: A tool for curriculum planning and evaluation. Medical Education, 34, 551-557. 
Harun, R. N. S. R. (2019). The construction and reconstruction of ESL student teachers' professional identity. Studies in English Language and Education, 6(1), 1-12.

Hoben, N. (2006). "Real teachers, real classrooms and real experiences": The work of associates with pre-service teachers on practicum (Unpublished doctoral thesis). University of Auckland, Auckland, NZ.

Iswandari, Y. A. (2016). Revealing pre-service foreign language teachers' imagined professional identity in reflective journals. Language and Language Teaching Journal, 20 (1), 59 67.

Johnson, K. E. (2009). Second Language teacher Education: A Sociocultural Perspective. New York, Routledge.

Lerseth, K. A. (2013). Identity development among pre service teacher candidates (Doctoral Dissertation). Iowa State University.

Nutriansi, M. (2015). The Perception of Teaching Practice Program Students of Pendidikan Bahasa Inggris on Micro Teaching Course in Sanata Dharma University. Yogyakarta: Universitas Sanata Dharma.

Norton, B., \& McKinney, C. (2010). An identity approach to second language acquisition. In D. Atkinson (Ed.), Alternative approaches to second language acquisition (pp. 73-93). New York, US: Routledge.

Malderez, A., A. J. Hobson, et al., (2007). Becoming a student teacher: core features of the experience. European Journal of Teacher Education 30 (3): 225-248.

Michelli, N. M., and Earley, P. M. (2011). Teacher education policy in context. In P. M. Earley, D. G. Imig, and N. M. Michelli (Eds.), Teacher education policy in the United States: Issues and tensions in an era of evolving expectations. New York: Routledge.

Miller, J. (2008). Teacher identity:. The Cambridge Guide to Second Language Teacher Education. A. Burns and J. C. Richards. Cambridge, Cambridge University Press.

Penuel, W. R., \& Wertsch, J. V. (1995). Vygotsky and identity formation: A sociocultural $\begin{array}{llll}\text { approach. } & \text { Educational } & \text { Psychologist, } & \text { 83-92. }\end{array}$ https://doi.org/10.1207/s15326985ep3002_5.

Phelan, A. (2005). A fall from someone else's certainty: Recovering practical wisdom in teacher education. Canadian Journal of Education. 28(3), 339-358.

Rodgers, C. R. \& Scott, K. H. (2008). The development of the personal self andprofessional identity in learning to teach. In M. Cochran-Smith, S. FeimanNemser, D. J. McIntyre \& K. E. Demers (Eds.), Handbook of Research on Teacher Education (pp, 732-755). New York: Routledge.

Salinas, D., \& Ayala, M. (2018). EFL student-teachers' identity construction: A case study in Chile. HOW, 25(1), 33-49. https://doi.org/10.19183/how.25.1.380.

Saphier, J., Haley-Speca, M.A. and Gower, R. (2008) The Skillful teacher: Building Your Teaching Skills. 6th Edition, Research for Better Teaching, Inc., Acton, 5. 
Scribner, S. (1997). A sociocultural approach to the study of mind. In E. Tobach, R. J. Falmangne, M. B. Parlee, L. M. W. Martin, \& A. S. Kapelman (Eds.), Mind and social practice: Selected writings of Sylvia Scribner (pp. 266-280). New York: Cambridge University Press.

Sleegers, P. \& Kelchtermans, G. (1999) Inleiding op het themanummer: professionele identiteit van leraren [Professional identity of teachers], Pedagogisch Tijdschrift, 24, 369-374.

Sutton, R. E., \& Wheatley, K. F. (2003). Teachers' Emotions and Teaching: A Review of the Literature and Directions for Future Research. Educational Psychology Review,15(4),327-358. https://doi.org/10.1023/A:1026131715856

Suwannaset, W \& Rimkeeratikul, S. (2014). "English Language Teaching Anxiety during Practical Teaching Experience of English Student Teachers", Burapha University, HRD Journal, Vol.5. No. 2, 2014

Taylor, S., \& Littleton, K. (2006). Biographies in talk: A narrative-discursive research approach. Qualitative Sociology Review, 2(1), 22-38.

Tsui, A. B. M. (2003). Understanding Expertise in Teaching; Case studies of ESL Teachers. Cambridge, Cambridge University Press.

Vygotsky, L. (1979). Consciousness as a problem in the psychology of behavior. Soviet Psychology, 17(4), 3-35.

$\mathrm{Xu}, \mathrm{H}$. (2013). Exploring the institutional and professional role cognitions of EFL teachers in junior high school. Beijing: Foreign Language Teaching and Research Press.

Yon, D. (2000) Elusive Culture: Schooling, race, and identity in global times, Albany, NY: State University of New York Press

Zacharias, N, T. (2010). The Teacher Identity Construction of 12 Asian ES Teachers in TESOL Graduate Programs. The Journal of Asia Tefl Vol. 7, No. 2, pp. 177-197, Summer 2010 .

Zepeda, S.J., Ilgan, A., \& Parylo, O. (2013). Peer coaching: Comparing the American and Turkish educators' willingness to adopt and implement peer coaching as a form of teacher professional development. International Journal of Mentoring and Coaching in Education, 2(1), 64-82. doi:10.1108/20466851311323096. 